\title{
SABINA ZALEWSKA
}

Faculty of Christian Philosophy, Cardinal Stefan Wyszyński University, Warsaw

\section{Environmental education with particular reference to management of municipal}

Key words: education, environmental education, recycling

\section{Summary}

In the pursuit of success, stuck in the shadow of reality, we often forget that every day we use goods of the environment which surrounds us. We do not realize that behavior of particular people, their families and social groups influences the elements of natural history. This article focuses on the adjustment of our lifestyle to the idea of balanced development. That is why environmental education, which supports understanding the correlation between man, his products and the environment, should be offered to all people, in particular the youngest, who will be able to direct the patterns of pro-environmental behavior to elderly people.

\section{Legal basis of environmental education}

It is the obligation of the State resulting from the Constitution of the Republic of Poland (A: No. 78, item 483) to ensure environmental protection, following the rule of balanced development. According to the law of environmental protection, the main point of the idea of balanced development is an integration of political, economical and social actions in the way which meets the basic needs of society, preserving the environmental balance for the current and future generations $(\mathrm{C}$ : 
No. 62 , item 627 with subsequent amendments). It is the environmental education that creates the shape of the relation between man, society and nature. Showing the dependence of man on nature, education focuses on the responsibility for changes in the natural environment (Ministry of the Environment, 2001b: 7-10). The environmental education for balanced development achieves the following targets:

- shaping the full consciousness and paying society's attention to links between political, social, economic and ecological issues,

- enabling the society to gain knowledge and skills needed to improve the shape of the environment,

- creating new patterns of behaviour, shaping attitudes, beliefs and values, including a care for the environment (ibid.).

The implementation of the above targets involves:

- assuming that environmental education is one of the conditions of the implementation of Environmental Policy of the State,

- implementing environmental education to all areas of social life (including cultural values, religion and ethics),

- enabling the society to obtain information about the condition of the environment

- assuming that environmental education is a fundamental condition of changing a consumption model of society (Ministry of the Environment, 200a: 7-10).

For the past 40 years, Poland has participated in many international conferences about environmental education. Documents issued during these meetings include recommendations which were taken into account in the National Strategy of Environmental Education. The strategy identifies and prioritizes main goals of environmental education as well as indicates ways of its implementation. The goals of the strategy are, among others, spreading the idea of eco-development in all areas of life, implementing environmental education at all levels of formal and non-formal education as well as promoting good experience of educational methodic (ibid.). 
The programme embraces both recipients of formal education and people lacking formal education in Poland, and it focuses on mutual support of these two forms of education (ibid).

The implementation of the strategy's recommendations, particularly educational tasks and the entity responsible for them, are included in the National Programme of Environmental Education. The programme constitutes a base for establishing voivodeship, district and community programmes of environmental education containing examples of educational projects for the local society (Ministry of the Environment, 2001b: 3-6).

The most important goals of the programme include:

- ensuring the proper scope of environmental education and embracing it to the complete system of citizen education,

- stimulating and profiling the development of environmental education in order to improve the environmental awareness in endangered areas or in nature-valuable areas,

- supporting institutions in accurate financing and searching for new sources of financial support for environmental education,

- preparing the Polish society for adjustments to the UE standards of nature protection,

- promotion of pro-ecological attitudes, behaviours and lifestyle helping to protect environment sources,

- supporting the process of creating structures responsible for environmental education in administration, non-governmental organizations, universities etc.,

- promoting active teaching focused on balanced development (Ministry of the Environment, Warsaw 2001a: 3 - 6).

\section{Environmental education in the educational system}

Environmental education appears with different frequencies in the curricula of many subjects - both in educational targets and tasks of the school, as well as in the contents of education and expected achievements 
of students (Ministry of the Environment, 2001b: 14). Education at particular stages of learning focuses on topics related to waste.

\subsection{Preschool education}

The kindergarten is an important stage in education, supporting parents in shaping the personality of man. Therefore, environmental education should start in the preschool age.

The core curriculum of preschool education names the goals which, among others, include:

- supporting children in developing skills and shaping intellectual activities needed in everyday situations and in further education;

- building a system of values, including educating children so they identify good and bad things better;

- building children's knowledge about social world, nature and technical world as well as developing skills of presenting their thoughts in the clear way (B: No. 4, item 17).

In kindergarten teaching schedules, the topic of natural environment appears more often. The goals at this stage include:

- acquiring conviction that man is a part of nature,

- observing, experimenting and discovering nature throughout the year,

- acquiring responsibility for the shape of nature which surrounds us (Web-01).

In the preschool curriculum, the topic of communal waste management is also included, in particular:

- studying sources of contamination of: water and soil, such as pouring wastewater or leaving waste in unauthorized places,

- understanding the need to limit the amount of waste e.g. multi-use packages like glass bottles and jars,

- using waste materials in art like newspapers, cardboard, styrofoam, jars etc.,

- understanding the necessity of segregating waste produced by man, learning about the economical aspect of collecting paper, as well as woods protection, 
- paying attention to the contamination of environment by waste during walks,

- getting used to leaving waste in proper containers,

- teaching waste segregation - leaving waste in marked containers, e.g. a piece of fabric to one container, a piece of textile to another, plastic to other one (ibid.).

Thus, the aims of pre-school education in shaping ecological awareness are primarily:

- triggering the desire and creating skills to observe natural environment,

- building sensitivity toward both beauty and damage in the environment,

- teaching the respect for other creatures,

- influencing the lifestyle and ecological awareness of parents,

- shaping habits and ecological behaviours in everyday life (Ministry of the Environment, 2001a: 13).

\subsection{Ist and IInd stage of education (the primary school)}

\section{I stage of education (early-school education)}

The goal of early-school education is to support children in their intellectual, emotional, social, ethical, physical and aesthetical development. It is important to raise a child in the way which enables a child to live in harmony with himself, people and nature. It is necessary that a child distinguish good and bad, be aware of his social membership (to a family, peer group and nation) as well as understand the need of taking care of nature (B: No. 4, item 17).

Environmental schooling at this stage consists of educating children in understanding and respecting animate and inanimate nature. This is why a third grade student of primary school should:

- know dangers to the environment caused by man such as: burning meadows and stubbles, polluting the air and water, wood fires, leaving waste and burning waste;

- undertake actions for environmental protection in his area: not leave waste, respect plants, remain silent in parks and forests, help animals survive winter and hot summer; 
- know that it is needed to segregate waste and understand the point of ecological packages;

- observe and conduct simple environmental experiences, analyze them and see cause and effect relationship (ibid.).

Ecological knowledge may be built just by education packages, information from the Internet and other sources of this kind. Environmental education should also be realized outdoors in nature. In classrooms, there should be seating nature. If it is impossible to keep plants and pets at school, classes in botanical gardens or farms are required (ibid.).

According to the recommendations of the National Environmental Education Programme the forms and contents of education for children of pre-school and early school age should be:

- variable, always attractive and very short, but repetitive with a simple interesting plot;

- focused on awakening the child's sensitivity to beauty, good, needs of others (Ministry of the Environment, 2001a: 31).

Forms of classes that have proven successful are competitions with prizes and searching for symbols of commonly accepted behaviours e.g. not leaving waste. In preschool education and early-school education a special emphasize should be put on:

- fostering respect for life and environmental sources,

- conducting classes outdoors (using nature trails),

- cooperating with centers of ecological education (ibid.).

\section{IInd stage of education (grade 4-6)}

The general goals of education with respect to the environment in upper grades of primary school are:

- raising students' interest in nature (searching for answers to questions: „why ?", „how is it?” or „what will happen when?”),

- formulating hypotheses about phenomena and processes taking place in the environment and verifying them (conducting observations and experiments, and taking down results), 
- practical application of environmental knowledge, distinguishing situations dangerous to health and life, undertaking actions increasing their and others' safety, acting consciously to protect their health,

- respecting nature (acting to protect the environment and culture heritage of the society),

- using various sources of information (one's own observations, research, experiences, texts, maps, schedules, photographs, films), taking measures, and following instructions (verbal, written, and graphical); documenting and presenting results of observation and experiments (B: No 4, item 17).

Teaching contents indicate that a schoolchild should, among others:

- conduct observations and simple experiments showing pollution of the nearest area (air, water, soil),

- explain the effect of everyday behaviour at home, school and playground on the shape of the environment,

- giving examples of sites in the nearest area in which useful and harmful changes have taken place due to human actions,

- giving examples of the positive and negative influence of the environment on human health (ibid.).

The school should provide conditions to conduct classes safely, both searching and outdoor classes, as well as classes involving observation and experiments. A part of classes involving observation and experiments should be making continuous or occasional references to e.g. changes of the seasons of the year or weather changes. In conducting classes, it is recommended to use everyday objects and products used at home (ibid.).

For this stage of education, The National Programme of Environmental Education recommends:

- participation of people from outside of school,

- collecting as many facts and opinions as possible,

- verification of popular opinions by experts and presenting results in a democratic way by means of voting and negotiations, 
- meticulous deliberation of ideas, as well as finding out the inhabitants' attitudes towards solutions to given problems (Ministry of the Environment, 2001b: 32).

\subsection{IIIrd stage of education (the secondary school)}

Environment-related topics are realized during various classes; most of them during biology classes, though. Therefore, at the $3 \mathrm{rd}$ and 4 th stage of education the requirements for teaching this topic are presented.

The most important goals of environmental education in the secondary school included in the core curriculum are:

- searching for, using and creating information by a schoolchild, using various sources and methods,

- reasoning and justifying (a schoolchild interprets information and explains cause and effect relationship between facts, makes and presents conclusions and opinions related to given biological issues (B: No. 4, item 17 ).

The teaching contents include the topic "Global and local problems of the environment", thanks to which a schoolchild:

- gives reasons and analyzes results of global warming,

- justifies the necessity of waste segregation, as well as the necessity of special disposal of used batteries, fluorescents, expired drugs,

- suggests actions in order to limit water and energy usage and the production of waste in the household (ibid.).

\subsection{IVth stage of education (the upper-secondary school)}

The general requirements for upper-secondary schools concerning environmental education are similar to the goals of the 3rd stage of education. According to the core curriculum, the attitudes towards nature and the environment should be shaped in upper-secondary schools, thanks to which students understand the necessity and importance of the protection of the environment as well as respect towards themselves and other living creatures. They can also describe how to use natural goods properly (ibid.). 
Classes are supposed to strengthen the scientific attitude of students towards nature, interest them in its richness, and encourage them to view science holistically. The content explores certain parts of the natural science referring to important issues of our civilization (ibid.).

Classes should be interdisciplinary and particular subjects may be taught by teachers of different specializations (physics, chemistry, biology, geography). Classes should be conducted by teachers with considerable experimental experience in a given field of science (ibid.).

In order to trigger and consolidate students' need to live in accordance with the idea of balanced development, the fundamental goal of the whole school society (principals, teachers, students and their parents) should involve taking the advantage of the contents of the programme. This can be achieved with:

- active forms of education,

- cooperation between teachers in creating the atmosphere which favours the fulfillment of fundamental goals of environmental education,

- communicating with local authorities and different representatives of the local society,

- participating in national and international programmes of environmental education,

- undertaking and popularizing actions at school and in the area in order to protect the environment,

- showing the positive role of children as part of educating the adults,

- conducting environmental education classes outdoors (Ministry of the Environment, 2001a: 14 -18).

According to the National Programme of Environmental Education, secondary and post-secondary school students are best targeted with attractive and innovative means, which are nevertheless not used by teachers in general. It is crucial to form independent opinions. Teaching should consolidate the proper treatment of natural resources, which is possible during indoor classes and workshops as well as outdoor classes. The participation of people from outside of school is also recommended (Ministry of the Environment, 2001b: 32). 


\subsection{Out-of-school environmental education}

The education for balanced development should be supported by actions of all central offices, in accordance with their specifications and profiles as well as proper programmes (Ministry of the Environment, 2001a: 14 -20). Actions related to environmental education should be integrated, beginning with the highest executive organs, and ending with local ones.

Locally made decisions directly affect man's environment in his place of residence. This is why local authorities are to define the goals and forms of education, taking into account the region, local identity and cultural tradition (ibid.). Local authorities should cooperate with organizations, workplaces, local community representatives in order to establish programmess of environmental education. Public administration organs should also cooperate with schools and ensure conditions to introduce environmental education (Ministry of the Environment, 2001b: 14 -20).

In order to increase the environmental awareness of the Poles, the following groups of people should receive environmental education:

- management of the administration of valuable natural areas (e.g. national parks, landscape parks, areas of Nature 2000, etc.),

- people who organise tourist and leisure trips,

- community organisations

- churches and religious associations (ibid).

2.6 Environmental education based on the municipal waste landfill in Przemyśl

Environmental education in the form of an educational path is a set of contents and skills of a crucial educational meaning, the realization of which can be implemented during compulsory or additional classes (ibid).

In this essay, I would like to present the educational path located in the area of a waste landfill with no hazardous and inert waste, managed by the Department of Public Utilities in Przemyśl. 
The aim of this educational path is, first of all, to draw local community's attention to the problems of waste management such as: the need to limit the amount of waste production, segregation, recovery of secondary raw materials. During classes, it is possible to get to know the rules of functioning of a municipal waste landfill. The educational path is an excellent supplement of classes shaping the ecological awareness at each stage of education (Public Utilities Department in Przemyśl, 2009). The theme of each checkpoint of the path can be part of classes or become scenarios of separate classes adjusted to age groups. The educational path in the municipal waste landfill consists of five checkpoints.

1. In the first checkpoint, located in front of the department, you can get to know the general plan of the department, its technical parameters and environmental infrastructure (ibid.), in particular:

- the type of landfill presented,

- why it was built and since when the new waste landfill in Przemyśl has functioned,

- the working hours of the department,

- the final capacity and durability of the landfill,

- the number of rooms the landfill consists of,

- activities run by the department,

- the procedure for accepting waste.

Depending on the information presented, the checkpoint can be adjusted to all the educational stages.

2. The second checkpoint is located at the technical building of the scales. The boards inform about ways of managing different types of waste. From here you can see an abattis for storing waste from the landfill; the waste was turned into recyclable materials thanks to landfill employees. Here are located objects that are typically used every day as well as containers for segregation. This is a perfect place to conduct educational classes for all the age groups, and the topics which can be discussed here are as follows: - what waste is and when a useful object becomes a piece of waste,

- what types of waste are distinguished,

- how to limit the amount of waste, 
- why waste segregation is recommended and how to segregate,

- whether each piece of trash is waste or recyclable material.

3. The third checkpoint is located in a separate part of the hall of workshop and warehouse building. Students can watch here a multimedia presentation about waste management, films about waste and how PET bottles are baled (ibid.). Depending on the presented multimedia material, this checkpoint can be adjusted to each educational stage, and the presentation of PET bottles pressing will be attractive for students of any age.

4. The fourth checkpoint is a view terrace, from which you can see almost all the area of the department, especially sites for disposing waste in three phases: pre-operating, operating and, partially, afteroperating phases (waste reclamation). An additional advantage is viewing the landfill at the time when new sites are being built. This checkpoint presents among other things:

- the technology for the storage of waste (pouring of waste into a pour square, transfer of waste to a separate plot of land, grading and concentrating of waste, covering of waste with an inert layer, etc.) and the cycle of work of machines,

- characteristics of a modern landfill, i.e. green belt insulation, weighbridge, disinfectant pool for cars, infrastructure for environmental protection (above-folic leachate drainage, geomembrane, pure water underfolic drainage, leachate reservoir with discharge line and sampling station, ditch, degassing wells and burners for combustion of biogas, barrier protecting from dispelling of parts of light waste).

5. The last checkpoint is located in south-west part of the department, at the retention reservoir of leachate.

The issue of protecting particular elements of the environment is presented here, especially:

- the method of separating rainwater and melt water into "pure” and "contaminated", so called leachate, 
- the method of groundwater sampling, and drainage of pure surface water and leachate,

- the scope and cycle of the monitoring of the environment and sampling points of surface water, groundwater, under-folic drainage water, rainwater and melt water, leachate, landfill gas, noise,

- current and future technology of landfill gas exploitation.

The topic of the last checkpoint makes it suitable for the third and fourth stage of education as well as for universities.

\section{Conclusion}

A Chinese proverb says: „If you foresee one year ahead - plant rice. If you foresee 10 years ahead - plant a tree. If you foresee 100 years ahead - teach people." The quotation indicates the point of environmental education, whose main goal is to make the society aware of the problems of the surroundings. Thanks to the education for balanced development, people are actively involved in solving environmental problems, learn facts and learn how to live in harmony with nature.

By creating the educational path of the landfill, the Public Utilities Department enabled the local inhabitants to learn about proper methods of municipal waste management and the way in which an ecological landfill functions. The scenarios mentioned above present various ways of using the path depending on the participants' age. The issues touched upon in these scenarios refer to the choices which waste producers make every day. The path is a perfect supplement of classes on environmental protection. New scenarios should be written in the future, referring to other problems of the co-existence of people and nature.

Educational centers in other departments, institutions and local centers whose activity can affect nature should also be established. This is the only way to teach the society about the impact of our actions on nature. 


\section{Bibliography}

Kafel K., Lenart W., Lewicka- Kłoszewska B., 1995, Którędy po Ziemi? Jak kształcić zgodnie z idea rozwoju zrównoważonego, Narodowy Fundusz Ochrony Środowiska, Warszawa.

Ministerstwo Środowiska, 2001a, Narodowy Program Edukacji Ekologicznej, Program wykonawczy Narodowej Strategii Edukacji ekologicznej i warunki jego wdrożenia, Warszawa.

Ministerstwo Środowiska, 2001b, Przez edukację do zrównoważonego rozwoju. Narodowa Strategia Edukacji Ekologicznej, Warszawa.

Soida D., 1993, Zasady i techniki edukacji ekologicznej. Organizujemy Zielona Szkołe, Kraków - Ojców.

Suchodolski B. et al, 1962, Zarys pedagogiki. System, ROEE, OPN, Warszawa.

Zakład Usług Komunalnych w Przemyślu, 2009, Ścieżka edukacyjna. Składowisko odpadów komunalnych w Przemyślu, WIOŚ, Przemyśl.

\section{Legislation:}

(A) Konstytucja Rzeczpospolitej Polskiej z dnia 2 kwietnia 1997 r. (Dz. U. z 1997 r., Nr 78, poz. 483).

(B) Rozporządzenie Ministra Edukacji Narodowej z dnia 23 grudnia 2008 r. w sprawie podstawy programowej wychowania przedszkolnego oraz kształcenia ogólnego w poszczególnych typach szkół (Dz. U. z 2009 r., Nr 4, poz.17).

(C) Ustawa z dnia 27 kwietnia 2001 r. Prawo ochrony środowiska (Dz. U. z 2001 r., Nr 62, poz. 627 z późn. zm.).

\section{Internet sources:}

(Web-01) Portal edukacyjny, <http://www.eduforum.pl/modules. php?name=Publikacje\&d_op=getit\&lid=3450>, accessed: 14.09.2012. 